\title{
GAYA KEPEMIMPINAN DALAM PENGAWASAN KERJA INTERNAL KPK TERHADAP KEDISIPLINAN KERJA DAN WORKPLACE WELL-BEING PEGAWAI
}

\author{
Fitrotul Imama ${ }^{1}$, Soffy Balgies ${ }^{2}$, Rohmatul Izzah Silvia ${ }^{3}$, Laily Safira Kamilaini ${ }^{4}$ \\ j91219103@student.uinsby.ac.id ${ }^{1}$, sbalgies@yahoo.com², \\ j91219126@student.uinsby.ac.id ${ }^{3}$, j91219109@,student.uinsby.ac.id ${ }^{4}$
}

Fakultas Psikologi dan Kesehatan UIN Sunan Ampel Surabaya

\begin{abstract}
ABSTRAK
Komisi Pemberantasan Korupsi atau yang biasa disingkat dengan KPK dikenal sebagai lembaga yang memiliki kuasa untuk memberantas korupsi di Indonesia. Tak heran jika hal-hal yang terdapat di KPK seperti gaya kepemimpinan, pengawasan kerja, disiplin kerja, dan lain sebagainya kerap mendapatkan atensi dan sorotan dari pemerintah hingga ke khalayak umum, serta kerap dikaji dari berbagai sudut pandang, termasuk dari sudut pandang psikologis. Tujuan dari kajian ini adalah untuk membahas tentang bagaimana kedisiplinan pegawai dalam internal KPK, berfokus pada bidang inspektorat yang baru dibentuk sebagai pelaku tindak disipliner beserta gaya kepemimpinan dan workplace well-being sehingga hasil kajian ini dapat bermanfaat untuk mencapai goals atau visi dan misi perusahaan dan organisasi. Studi literatur yang digunakan dalam kajian ini bersumber dari buku, jurnal, serta berita-berita yang memuat teori-teori serta pendapat para ahli mengenai fokus yang dibahas. Kajian ini mengaitkan antara halhal yang terdapat dalam internal KPK dengan sudut pandang psikologi industri dan organisasi.

Kata Kunci: KPK, Gaya Kepemimpinan, Pengawasan Kerja,

Disiplin Kerja, workplace well-being.
\end{abstract}

\begin{abstract}
Komisi Pemberantasan Korupsi or commonly abbreviated as the KPK is known as an institution that has the power to eradicate corruption in Indonesia. It is not surprising that matters contained in the KPK such as leadership style, work supervision, work discipline, etc. often get attention and spotlight from the government to the general public, and are often studied from various points of view, including from a psychological point of view. The purpose of this study is to discuss how the discipline of employees within the KPK internally, focuses on the newly formed inspectorate field as actors of disciplinary action along with leadership styles and workplace well-being so that the results of this study can be useful for achieving the goals or vision and mission of the company and organization. . The literature study used in this study comes from books, journals, and news that contain theories and opinions from experts regarding the focus discussed. This study links matters contained within the Corruption Eradication Commission (KPK) with the perspective of industrial and organizational psychology.

Keywords: KPK, Leadership Style, Work Supervision, Work Discipline, Workplace well-being.
\end{abstract}




\section{PENDAHULUAN}

Suatu perubahan dalam peraturan perundang-undangan dapat terjadi dan dilakukan dengan tujuan untuk mengurangi, menambah, dan/atau menghapus ayat-ayat atau pasal-pasal di dalam perpu atau peraturan perundang undangan sebelumnya. Sehingga nantinya, setelah terjadi perubahan, perundang-undangan yang baru diberlakukan di samping dengan beberapa perundang-undangan lama yang masih akan tetap digunakan dengan catatan belum diubah atau direvisi dengan perpu terbaru.

Hal ini bisa juga disamakan sesuai perubahan pada undang-undang, yang mana pada undang-undang ini masih merupakan bagian perpu atau peraturan perundangundangan. Yang berwenang until mengubah perundang-undangan maupun undangundang ini adalah DPR (yang memiliki kepanjangan Dewan Perwakilan Rakyat), yang kemudian nantinya akan dipertimbangkan lebih lanjut serta disetujui oleh Presiden. Lembaga negara inilah yang juga memiliki wewenang sebagai pembentuk undangundang (Telaumbanua, 2020)

Komisi Pemberantasan Korupsi (atau yang biasa disingkat dengan KPK) barubaru ini mengeluarkan Perkom atau Peraturan Komisi Nomor 7 Tahun 2020 yang berbicara mengenai Organisasi dan Tata Kerja KPK. Ada setidaknya sembilan belas bidang yang baru saja dibentuk melalui aturan itu, yang mana salah satunya merupakan bidang Inspektorat. Inspektorat memiliki tugas untuk memeriksa pelanggaranpelanggaran disiplin yang memiliki tujuan supaya nantinya pemimpin akan lebih efektif lagi ketika melakukan kontrol pengawasan kepada kinerja yang berada dalam komisi pemberantasan korupsi.

Kepemimpinan didefinisikan sebagai cara seseorang untuk dapat memberikan pengaruh kepada orang lain supaya mendapat motivasi sehingga orang tersebut dapat menyelesaikan pekerjaan tanpa adanya tekanan. Untuk mempengaruhi orang lain diperlukan strategi kepemimpinan yang efektif agar anggota organisasi dapat berkontribusi secara maksimal (Setiawan \& Mardalis, 2015). Gaya kepemimpinan merupakan tolak ukur dari pengembangan organisasi karena dengan menerapkan gaya kepemimpinan yang tepat maka dapat mencapai tujuan organisasi dengan baik dan mudah. Karena gaya kepemimpinan ini menjadi suatu cara seseorang untuk dapat memberikan pengaruh terhadap seluruh anggotanya. Tingkah laku dan motif yang dilakukan oleh seorang atasan atau pemimpin merupakan perpaduan antara filosofi, 
keterampilan, sifat, dan sikap (Permana et al., 2019). Ada tiga macam gaya kepemimpinan, yaitu:

1. Gaya kepemimpinan otoriter

Pemimpin yang menerapkan gaya kepemimpinan otoriter cenderung memegang seluruh tanggung jawab dan semua keputusan berpusat pada dirinya. Sedangkan bawahan hanya mengikuti dan melaksanakan kebijakan yang telah diatur oleh pimpinan.

2. Gaya kepemimpinan demokratis

Pemimpin yang menerapkan gaya kepemimpinan demokratis cenderung memiliki empati yang tinggi, selalu menghargai kemampuan para pegawainya. Memberikan motivasi dan arahan kelompok untuk mencapai tujuannya sendiri. Segala informasi bersifat terbuka.

3. Gaya kepemimpinan bebas

Pemimpinan yang memberikan kepercayaan penuh kepada pegawainya untuk bersikap mandiri serta memberikan kesempatan para pegawai untuk mengambil keputusan dan mengelola kemampuannya namun tetap memberikan arahan agar tetap dapat menyelesaikan tugas-tugas yang berkaitan dengan tugas organisasi.

Seorang pemimpin harus memiliki sifat yang efektif, yaitu: 1) menjalin hubungan yang baik, 2) emosi yang stabil, 3) sikap yang optimis, 4) memiliki karakter yang kuat, 5) mencapai kemoderatan orientasi, 6) semangat tinggi dan dapat mengelola stres, 7) memiliki dorong yang kuat, dan 8) bersifat dewasa. Menurut Hughes, dkk (2002) pemimpin dapat dikatakan efektif yaitu harus berkepribadian dan bersifat baik. Ada faktor yang dapat mempengaruhi model kepribadian, yait; kekacauan, ramah, jujur, dapat beradaptasi, dan berintelektual (Sudharta, 2017)

Selanjutnya, seorang pemimpin harus menetapkan gaya kepemimpinannya dengan tujuan memberikan jaminan keamanan dan kenyaman pegawai dalam bekerja sehingga mampu meningkatkan motivasi dalam bekerja. Jika gaya kepemimpinan tepat maka disiplin kerja juga akan meningkat namun jika gaya kepimpinan tidak tepat maka disiplin kerja juga akan menurun karena karyawan akan merasa tidak adanya perhatian dan pengawasan dalam bekerja. Pemberian motivasi dalam bekerja juga dapat menjadi pengaruh disiplin kerja. Memotivasi karyawan dapat menjadi stimulus agar karyawan memiliki semangat dalam bekerja sehingga produkivitas kerja juga dapat meningkat. Ketika seorang karyawan telah memiliki motivasi yang kuat maka dengan kesadaran diri untuk bertindak disiplin dalam bekerja (Rahmi et al., 2020) 
Untuk memastikan adanya perhatian pada pegawai dalam hal tanggung jawab atas hasil dan kinerja pengelolaan, diperlukan pengawasan yang setinggi-tingginya. Geoge R. Terry, menyebutkan “control” yang dikutip oleh Muhsan dalam (Hamzah, 2020) sebagai berikut:

"control is the means to determine achievement, evaluate it, and implement corrective action, if necessary to ensure the results are consistent with the results. " artinya pengawasan adalah upaya untuk menentukan pencapaian, mengevaluasi dan menerapkan langkah-langkah inovatif dan memastikan bahwa hasil sesuai dengan rencana bila diperlukan. Ada lima hal yang harus dipenuhi untuk melakukan perilaku pengawasan berikut ini:

a. Aparat penegak hukum memiliki kewenangan yang jelas

b. Sebuah rencana yang dapat digunakan sebagai cara untuk menguji kinerja tugas yang akan dimonitor

c. Memantau aktivitas yang sedang berlangsung terhadap hasil yang diperoleh dari aktivitas tersebut

d. Tindakan pengawasan diakhiri dengan pernyataan penilaian akhir dari kegiatan yang dilakukan dengan mencocokkan hasil yang dicapai dengan rencana

e. Tindakan pengawasan akan ditindaklanjuti dalam aspek administrasi dan peradilan

Fachrudin (2004, dalam Tjandra, 2006: 133, dalam (Iskandar, 2019) mengidentifikasi beberapa sudut pandang untuk menentukan jenis pengawasan. Pertama, pengawasan dari sudut pandang kelembagaan. Ada dua kategori untuk jenis ini: a) Pengendalian internal yaitu pengawasan oleh suatu instansi atau organisasi yang masih merupakan internal organisasi pemerintahan. Bentuk kontrol ini dapat dibagi menjadi kontrol manajemen teknis atau built-in control; (b) Pengawasan dari segi kemanfaatan (opportunity) pengawasan dilakukan untuk menilai aspek manfaat (doelmatigheid). Dari segi hukum dan kepentingan, pengendalian internal oleh atasan merupakan evaluasi. Kategori kedua adalah metode pengawasan dari pengawasan Jenis ini juga memiliki dua macam, yakni: a) Pengawasan represif setelah melakukan tindakan; (b) Pengawasan pencegahan atau pemantauan aktif. Pengawasan oleh aparat pemerintah tingkat atas mengesampingkan kelalaian pemerintah tingkat bawah.

Hal-hal tersebut berhubungan dengan disiplin kerja dan workplace well-being. Disiplin merupakan kemampuan untuk mengontrol perilaku dalam diri individu sesuai 
dengan norma luar atau norma yang ada. Dengan kata lain, dari sudut pandang psikologis, disiplin adalah perilaku orang yang nampak dan dapat beradaptasi dengan aturan yang ditetapkan (Prof. James Drever, 1910-1991, filsuf dari University of Dundee, Skotlandia dalam Budhi, 2017). Adapun tujuan disiplin kerja yaitu untuk mencapai suatu tingkah laku dan perbuatan yang sesuai dengan standar ketentuan yang berlaku dan menciptakan rasa hormat dan saling percaya antara supervisor dengan bawahannya. Pada hakikatnya disiplin memiliki tiga jenis sifat (Keith Davis \& John W, Newstrom dalam Organizational Behavior: Human Behavior at Work, 2002 dalam Budhi, 2017):

1. Preventif

2. Korektif

3. Progresif

Disiplin preventif mengacu pada perilaku sumber daya manusia, sehingga termotivasi untuk mematuhi standar dan peraturan agar tidak ada pelanggaran atau pada hakikatnya perilaku preventif tanpa adanya pemaksaan. Oleh karena itu perlu dilakukan beberapa hal untuk mencapai tujuan tersebut:

1. Karyawan memahami dan mentaati standar yang berlaku

2. Aturan standar harus jelas dan tidak ambigu

3. Karyawan turut serta menetapkan ketentuan disipliner

4. Ketentuan harus bersifat pasti, tegas, dan nyata

5. Semua bagian dalam organisasi sepenuhnya turut serta (integrasi)

6. Menegaskan adanya ketentuan tidak hanya untuk keperluan pembuat aturan, namun juga untuk kebaikan semua orang dalam organisasi (komunitas).

Meskipun standar ketentuan telah ditetapkan, namun hal tersebut tidak membuat pelanggaran tidak terjadi. Oleh karena itu, penting menerapkan tindakan disiplin korektif yaitu tindakan pencegahan terulangnya insiden disipliner dan tidak akan ada pelanggaran di lain waktu. Dalam hal ini, tindakan yang dilakukan biasanya berupa sanksi tertentu yang sering disebut sebagai tindakan disipliner, seperti mengeluarkan surat peringatan, skorsing atau bahkan hukuman yang paling berat, diikuti dengan prosedur pemecatan (pemutusan hubungan kerja atau PHK). Hal-hal tersebut mendidik dan bertujuan untuk meningkatkan perilaku serta mencegah orang lain melakukan tindakan serupa akibat sanksi serupa. Oleh karena itu, terdapat dampak psikologis untuk meredam pekerja lainnya bertindak hal yang salah karena akan mendapat ganjaran yang sama. 
Disiplin progresif mengandung arti tindakan hukuman berat yang terjadi atas pengulangan pelanggaran. Bertujuan memungkinkan pelanggar hukum untuk mengintropeksi diri sebelum mendapat tindakan disipliner yang lebih berat. Disiplin progresif berupaya menyelesaikan persoalan melalui pemberian sanksi berdasarkan pelanggaran yang diperbuat. Menurut penelitian Singodimerjo (2000) dalam (Dessler, 2017) faktor-faktor yang berpengaruh dalam kedisiplinan karyawan antara lain:

1. Ukuran pemberian imbalan

2. Hal yang dapat ditiru dari pemimpin dalam perusahaan.

3. Ketentuan yang telah ditetapkan

4. Keberanian tindakan yang diambil oleh pemimpin.

5. Kontrol dari pemimpin

6. Adanya kepedulian kepada para karyawan

7. Menciptakan pola yang menunjang penegakan kedisiplinan.

Dalam menilai disiplin keja pegawai, ada aspek-aspek penilaian pada disiplin kerja yang harus diketahui yakni Kejujuran dalam melaksanakan tugas dan tanggungjawab; Ketepatan waktu karyawan dalam mengerjakan pekerjaan dengan penggunaan waktu kerja yang sepenuhnya dan seefisien mungkin; Kehadiran dalam bekerja; Mengikuti cara bekerja yang telah ditentukan oleh perusahaan yaitu kepatuhan terhadap peraturan kerja; Cara berpakaian, dan Ketepatan dalam penggunaan bahan dan perlengkapan

Pengertian workplace well-being merujuk pada apa yang disampaikan oleh Page (2005) dalam (Kurniadewi, 2016) yakni mendefinisikan Workplace well-being sebagai emosi positif dan kesejahteraan yang didapatkan oleh karyawan ketika bekerja dan perasaan secara keseluruhan yang dirasakan pegawai serta rasa puas yang diperoleh dari dua unsur yakni unsur intrinsik dan ekstrinsik. Dimensi intrinsik kesejahteraan di tempat kerja terdiri dari aspek-aspek mengenai perasaan pegawai terkait tugas yang dimiliki dalam ranah kerja mereka. Faktor ini terdiri dari lima aspek, yaitu: (a) tanggungjawab dalam kerja, (b) makna pekerjaan, (c) kemandirian dalam pekerjaan, (d) penggunaan kemampuan dan pengetahuan dalam kerja, serta (e) perasaan berprestasi dalam bekerja. Sementara itu, dimensi ekstrinsik kesejahteraan di tempat kerja terdiri dari aspek-aspek mengenai perasaan pegawai terkait lingkungan pekerjaan. Faktor ini terdiri dari delapan aspek yakni: (a) penggunaan waktu yang sebaik-baiknya, (b) kondisi kerja, (c) supervisi, 
(d) peluang promosi, (e) pengakuan terhadap kinerja yang baik, (f) penghargaan sebagai individu di tempat kerja, (g) upah, dan (h) keamanan pekerjaan.

Menurut Bakker dan Demerouti dalam (Wulan \& Putri, 2016) hal-hal yang berpengaruh dalam workplace well-being terdiri atas:

a. Job Demands: kebutuhan pekerjaan mengacu pada aspek fisik, psikologis, sosial atau organisasi dari pekerjaan yang membutuhkan upaya atau kemampuan fisik dan/ atau mental yang berkelanjutan

b. Job Control: pegawai memiliki hak untuk menggunakan keterampilan mereka untuk mengontrol dan membuat keputusan tentang pekerjaan yang mencakup melakukan kebebasan kerja sesuai dengan job description, menentukan waktu istirahat dan pengambilan keputusan.

c. Job Resources: prestasi kerja yang mengacu pada pekerjaan fisik, psikologis, sosial atau organisasi yang berperan dalam mencapai tujuan kerja, dan perkembangan pribadi.

Oleh karena itu kepuasan kerja yang didapat merupakan konsep dalam penilaian seseorang yang mengacu pada kesejahteraan di tempat kerja. Maka konsep workplace well-being dinilai sama dengan konstruksi subjective well-being dan psychological wellbeing karena sama-sama membangun pola kesehatan mental pekerja (Kurniadewi, 2016). Diharapkan individu yang memiliki kesejahteraan subjektif di tempat kerja dapat mengoptimalkan pengetahuan dan kemampuannya sehingga dapat menyelesaikan pekerjaannya dengan baik, sehingga kinerja yang dihasilkan juga bermanfaat bagi perusahaan (Mubyl et al., 2019). Well-being sangat erat kaitannya dengan kesuksesan di tempat kerja, dimana karyawan yang bahagia akan meningkatkan efisiensi kerja dan memiliki disiplin kerja yang baik (Kurniadewi, 2016).

Oleh karena itu, kajian ini berfokus pada bidang inspektorat yang baru dibentuk sebagai pelaku tindak disipliner beserta gaya kepemimpinan yang ditunjukkan terhadap kedisiplinan dan workplace well-being pegawai intern KPK. Tujuan penulis mengangkat topik kajian ini adalah untuk membahas tentang bagaimana kedisiplinan pegawai dalam internal KPK dan workplace well-being sehingga hasil kajian ini dapat bermanfaat untuk mencapai goals atau visi dan misi perusahaan dan organisasi.

\section{METODE}

Penulis menggunakan metode penelitian kepustakaan atau kajian literatur yang 
berkaitan dengan topik yaitu mengenai pengaruh dari gaya kepemimpinan terhadap kedisiplinan dan workplace well-being bagi para pegawai. Literatur yang digunakan penulis yaitu beberapa buku, jurnal, dan berita sesuai dengan isu yang dibahas. Sementara itu, penulis juga mencari literatur denga memanfaatkan media online untuk mendukung pemenuhan kebutuhan analisis data. Dalam hal ini, literatur penunjang tersebut yaitu memanfaatkan beberapa berita online dari situs web milik kompas dan CNN Indonesia yang membahas mengenai isu KPK.

Dari tiga sumber literatur, penulis menghasilkan sebuah artikel yang akan memaparkan keterkaitan antara gaya kepemimpnan dengan kedisiplinan dan workplace well-being bagi para pegawai KPK.

\section{HASIL DAN PEMBAHASAN}

Komisi Pemberantasan Korupsi atau KPK dipimpin oleh seorang ketua dengan 4 wakil ketua KPK. Dewan Perwakilan Rakyat memiliki wewenang untuk memilih para pemimpin KPK sesuai dengan usulan Presiden. Dalam mengusulkan calon-calon pemimpin KPK, Presiden memiliki beberapa pertimbangan yaitu kemampuan, profesional, berprinsip, keberanian, dan partai politik. Berdasarkan hasil survey pada tahun 2018 didapatkan bahwa angka kepercayaan masyarakat terhadap Komisi Pemberantasan Korupsi menurun dari angka 89,0\% menjadi 85,7\%. Penyebab menurunnya kepercayaan tersebut akibat dari cara kepemimpinan pimpinan baru KPK yaitu Firli Bahuri.

Ketua pimpinan KPK dinilai menerapkan gaya kepemimpinan yang otoriter dimana gaya kepemimpinan ini cenderung memegang seluruh tanggungjawab dan semua keputusan berpusat pada dirinya, sedangkan bawahan hanya mengikuti dan melaksanakan kebijakan yang telah diatur oleh pimpinan. Hal ini membuat ketua pimpinan KPK mengambil keputusannya sendiri tanpa adanya kesepakatan antara dua belah pihak seperti pada pemberitaan kasus suap dimana ketua pimpinan KPK tiba-tiba menunjukkan perilaku misterius dengan tanpa alasan mengembalikan pegawai negeri yang dipekerjakan untuk dilakukan penyidikan oleh pihak POLRI dan Kejaksaan Agung. Tindakan tersebut menimbulkan kecurigaan terhadap pimpinan KPK karena dinilai mengganggu dan terkesan menghalang-halangi proses penyidikan yang sedang berjalan.

Salamadian (2018) dalam (Tama \& Hardiningtyas, 2017) berpendapat ketika gaya kepemimpinan ini diterapkan, maka bawahan diharuskan untuk menuruti keputusan 
yang diambil oleh pemimpin tersebut tanpa perlu mempertimbangkan ide, gagasan, serta saran dari bawahan, sehingga nantinya berpotensi menimbulkan sikap apatis pada masing-masing bawahan. Gaya kepemimpinan yang otoriter akan memberikan dampak negatif bagi lingkungan kerja sehingga dapat menurunkan kinerja para pegawai karena merusak sistem yang telah dijalankan oleh KPK dan terkesan tidak peduli dengan keadaan ataupun situasi yang terjadi dalam organisasi. Seorang pemimpin harus memiliki sifat yang efektif artinya pemimpin dapat menjalin hubungan yang baik dan memiliki karakter yang kuat. Namun dalam kenyataannya, pimpinan KPK justru tidak dapat menjalin hubungan yang baik karena gaya kepemimpinan yang otoriter. Karakter kuat dalam gaya kepemimpinannya justru akan berakibat pada kinerja pegawainya.

Namun dalam gaya kepemimpinan tersebut pimpinan melakukan pengawasan yang dilakukan oleh badan Inspektorat. Dalam menjalankan tugasnya sebagai pengawas kinerja pegawai, badan inspektorat akan melaporkan hasil pengawasannya kepada pimpinan KPK dengan kata lain, pimpinan KPK memiliki gaya kepemimpinan dalam pengawasan melalui badan Inspektorat. Pengawasan yang dilakukan badan Inspektorat merupakan pengawasan kelembagaan yang bersifat pengendalian internal dengan maksud pengawasan oleh suatu instansi atau organisasi yang masih merupakan internal organisasi pemerintahan. Pengawasan ini juga bertujuan untuk mengontrol perilaku dalam diri individu sesuai dengan norma atau aturan yang ada dimana dalam kasus ini adalah aturan yang ada di dalam instansi KPK.

Hal ini sesuai dengan teori yang dikemukakan oleh Fachrudin dalam (Iskandar, 2019) yaitu pengawasan internal merupakan pengawasan oleh suatu instansi atau organisasi yang masih dalam lingkup internal organisasi pemerintahan. Dari segi hukum dan kepentingan, pengawasan internal ini melakukan pengawasan represif yakni pengawasan setelah adanya tindakan dan pengawasan pencegahan atau pemantauan aktif agar tidak ada terjadinya tindakan yang melanggar hukum. Pengawasan oleh badan inspektorat menitikberatkan pada kedisiplinan pegawai dalam melakukan pekerjaan yang sesuai dengan standar ketentuan yang ditetapkan. Adapun fungsi pengawasan oleh badan inspektorat sesuai dengan yang dinyatakan oleh Terry yang dikutip oleh (Hamzah, 2020) yaitu sebagai tolok ukur atas pencapaian yang sudah tercapai, lantas dapat menjadi evaluasi agar menjadi lebih baik lagi kedepannya.

Pimpinan pada gaya kepemimpinannya dalam pengawasan kerja pegawai 
lingkup internal KPK telah ditetapkan dan dilakukan oleh badan inspektorat, di mana laporan akan diberikan langsung kepada pimpinan KPK. Badan Inspektorat memiliki tugas untuk memeriksa pelanggaran-pelanggaran disiplin yang dilakukan seluruh pegawai internal KPK. Adapun peraturan disiplin pegawai KPK dalam peraturan nomor 10 tahun 2016 antara lain:

1. Mentaati kode etik

2. Mentaati sumpah/janji dan sumpah jabatan

3. Menyimpan rahasia negara/pekerjaan/jabatan yang menurut perintah harus dirahasiakan

4. Patuh dalam pelaksanaan tugas dan pekerjaan sesuai dengan prosedur operasi baku yang berlaku di KPK

5. Memakai kartu identitas pegawai selama waktu kerja baik di dalam maupun di luar lingkungan KPK

6. Berpakaian dan berpenampilan rapi, bersih dan sopan

7. Mentaati peraturan sistem manajemen keamanan informasi dan data

8. Menjaga dan memelihara barang-barang yang digunakan atau diperoleh dalam pelaksanaan tugas

9. Hadir dan pulang kerja sesuai ketentuan yang berlaku

10. Melaporkan secepatnya kepada atasan atas keterlambatan atau ketidakhadiran di tempat tugas

11. Melaksanakan tugas dan tanggungjawab dengan baik, cermat dan teliti sehingga tidak menimbulkan kerugian keuangan negara

Peraturan tersebut merupakan jenis disiplin preventif yakni tindakan disiplin untuk pencegahan adanya pelanggaran disiplin yang diberikan ketika seseorang pertama kali bergabung pada perusahaan. Hal ini mengacu pada perilaku sumber daya manusia, sehingga termotivasi untuk mematuhi standar dan peraturan agar tidak ada pelanggaran tanpa adanya pemaksaan. Dengan adanya aturan standar yang jelas dan pegawai memahami serta mematuhi standar yang berlaku, hal tersebut mendukung untuk mencapai tujuan disiplin preventif. 
Namun meski standar ketentuan telah ditetapkan, beberapa pelanggaran tetap terjadi. Oleh karena itu adanya penerapan tindakan disiplin korektif yaitu tindakan pencegahan terulangnya insiden disipliner dan tidak akan pelanggaran di lain waktu. Dalam hal ini tindakan yang dilakukan biasanya berupa sanksi tertentu seperti mengeluarkan surat peringatan. Pada september tahun 2020, Ketua pimpinan KPK terbukti melakukan pelanggaran kode etik yaitu gaya hidup mewah. Dengan adanya pelanggaran tersebut, bersangkutan dijatuhi sanksi ringan berupa teguran tertulis 2 yang sesuai dengan tindakan disipliner korektif. Disiplin korektif merupakan tindakan disiplin yang mencegah terulangnya insiden disipliner dan tidak akan ada pelanggaran di lain waktu. Dalam hal ini, tindakan yang dilakukan biasanya berupa sanksi tertentu seperti mengeluarkan surat peringatan.

Pada bulan yang sama, Ketua Wadah Pegawai KPK dilaporkan atas dugaan penyebaran informasi dan dianggap melanggar kode etik sehingga mendapatkan sanksi ringan dengan SP1 tertulis. Hal ini dimungkinkan terjadi karena adanya ketidak baikan contoh yang diberikan oleh ketua pimpinan kepada karyawan. Salah satu faktor yang berpengaruh dalam kedisiplinan pegawai adalah hal yang dapat ditiru dari pimpinan dalam perusahaan sehingga apa yang dilakukan pimpinan akan menjadi suatu cara seseorang untuk dapat memberikan pengaruh terhadap seluruh anggotanya. Oleh karena itu, tindakan disipliner tersebut mendidik dan bertujuan untuk meningkatkan perilaku serta mencegah orang lain melakukan tindakan serupa akibat sanksi serupa.

Selain itu, dalam menegakkan kedisiplinan pegawai, ada tindakan disipliner dengan tindakan pemotongan gaji, pembebasan dari jabatan dan diberhentikan tidak hormat dalam hukuman disiplin berat yang diberikan badan inspektorat kepada pegawai yang berulang kali melakukan pelanggaran atau dapat disebut dengan tindakan disiplin progresif yang mengandung arti tindakan hukuman berat atas pengulangan pelanggaran. Penelitian yang dilakukan (Yudi Prawira Jaya \& Dewi Adnyani, 2015) pada pengaruh gaya kepemimpinan terhadap disiplin kerja pegawai di Dinas Balai Bahasa Provinsi Bali menunjukkan adanya keterkaitan gaya kepemimpinan seorang pemimpin terhadap kedisiplinan pegawai yang sekaligus dapat menciptakan suasana kerja yang nyaman dan harmonis.

Pegawai perusahaan adalah aset penting bagi perusahaan. Adanya workplace well-being terjadi karena kelekatan emosi dalam pekerjaan yang mempengaruhi 
kedisiplinan pegawai. Well-being yang dirasakan seorang pegawai diasosiasikan dengan kesuksesan di tempat kerja, dimana seorang pegawai yang bahagia akan lebih produktif. Kesejahteraan pegawai merupakan hal yang tidak dapat lepas dari isu penting dalam suatu perusahaan dimana hal tersebut akan berhubungan langsung terhadap fisik, psikologis, dan perilaku pegawai. Badan Inspektorat yang memiliki tugas sebagai pengawas menemukan adanya 38 pegawai sejak januari 2020 mengundurkan diri sebagai pegawai KPK karena perubahan UU yang dilakukan oleh pimpinan KPK, mengakibatkan pegawai tidak merasakan kepuasaan dalam pekerjaannya. Hal tersebut menandakan adanya ketidaksejahteraan yang dialami pegawai dalam tempat kerja, sesuai dengan faktor ekstrinsik adanya workplace well-being yakni kondisi lingkungan kerja. Selain itu ditemukan adanya pelanggaran oleh ketua KPK, peran pemimpin dalam menciptakan workplace well-being sangat diperlukan yang akan berhubungan dengan kinerja dan disiplin kerja pegawai.

Penelitian dalam jurnal internasional Effect of Leadership Style, Motivation and Discipline of Employee Performance (Razak et al., 2018) menunjukkan bahwa gaya kepemimpinan berpengaruh signifikan terhadap kinerja pegawai dan disiplin kerja berpengaruh signifikan terhadap kinerja pegawai. Sejalan menurut teori, kepemimpinan adalah cara seorang pemimpin untuk mengarahkan aktivitas bawahannya agar bekerja sama, bekerja secara efektif dan efisien untuk mencapai tujuan. Hal yang sama dibuktikan dalam penelitian yang dilakukan pekerja di Samarinda.

Kepemimpinan yang baik pada dasarnya akan memberi motivasi bawahan untuk berbuat lebih dari apa yang biasa dilakukan. Workplace well-being sejatinya merupakan pengaplikasian dari subjective well-being dimana workplace wellbeing yang tinggi akan mempengaruhi seluruh kegiatan pegawai secara positif. Namun apa yang terjadi sekarang dalam pemberitaan nasional oleh Suhendra (2020) menyebutkan bahwa salah satu persoalan utama di KPK saat ini adalah ketidakteladanan pada tingkat pimpinan karena ketua KPK pun merupakan sosok yang telah terbukti melanggar kode etik kepegawaian artinya melakukan pelanggaran kedisiplinan pegawai. Hal ini akan menjadi beban moral kelembagaan tak terkecuali pada seluruh pegawai KPK karena kesejahteraan di tempat kerja tidak berjalan dengan baik dalam mentaati peraturan. Selain itu adanya kasus ini mempengaruhi job demands pegawai dalam merasakan workplace well-being. Job demands maupun resources merupakan dua hal psikologis 
yang mendasari peran dalam kesejahteraan pegawai dimana tuntutan pekerjaan yang berlebihan dan kurangnya sumber daya pekerjaan menyebabkan kebingungan. selain itu, job control pegawai dalam hal ini yang mengacu pada kebebasan kerja sesuai dengan job description tidak berjalan dengan karena adanya gaya kepemimpinan otoriter pimpinan kpk saat mengambil keputusan secara sepihak. Oleh sebab itu, pimpinan kerja memiliki keterkaitan adanya workplace well-being pegawai saat berada di tempat kerja sehingga mampu untuk meningkatkan kinerja dalam bekerja dan mencapai tujuan organisasi.

Dalam beberapa penelitian menyebutkan adanya karakteristik pekerjaan yang dapat mempengaruhi workplace well-being diantaranya kejelasan lingkungan, peluang untuk kontak personal, keadilan, dan upah. Hal tersebut sesuai dengan yang dikemukakan oleh Sutrisno (2019) dalam faktor-faktor yang mendukung adanya kedisiplinan pegawai yakni, ukuran pemberian imbalan, pengawasan pimpinan, aturan yang jelas, dan adanya kepedulian kepada para pegawai. Hal tersebut membuktikan adanya keterkaitan antara gaya kepemimpinan yang baik dalam pengawasan kerja akan mempengaruhi workplace well-being pegawai dan disiplin kerja, sehingga membuat karyawan menikmati dan melakukan pekerjaannya dengan baik. Dalam (Yusuf, 2018) juga mengemukakan bahwa pegawai yang memiliki rasa tanggung jawab akan melakukan pekerjaan dengan baik dan memiliki kesejahteraan yang baik di tempat kerja.

\section{SIMPULAN DAN REKOMENDASI}

Dari kajian ini, dapat ditarik keputusan bahwa ketua pimpinan KPK dinilai menerapkan gaya kepemimpinan yang otoriter yang kemudian berdampak negatif bagi lingkungan kerja sehingga dapat menurunkan kinerja para pegawai. Disisi lain, badan Inspektorat yang bernaung langsung dibawah pimpinan KPK sejauh ini melaksanakan tugasnya dengan cukup baik dengan menerapkan peraturan-peraturan yang termasuk ke dalam jenis disiplin preventif jika dilihat dari sudut pandang psikologi industri dan organisasi. Namun, adanya 38 pegawai yang mengundurkan diri di tahun 2020 serta adanya pelanggaran yang dilakukan oleh ketua KPK mencerminkan bahwa ada ketidaksejahteraan yang dialami pegawai dalam tempat kerja. Hal ini juga merupakan dampak dari ketidakteladanan pada tingkat pimpinan yang menjadi persoalan utama di KPK saat ini. Berdasarkan uraian pada pembahasan di atas dapat diketahui bahwasanya, gaya kepemimpinan seorang pimpinan akan mempengaruhi kedisiplinan pegawai dan workplace well-being pegawai dalam meningkatkan kinerja dan tujuan organisasi yang 
terjadi karena perasaan memiliki tanggung jawab dalam pekerjaan dan mentaati peraturan.

Sebagai penutup dari artikel ini, penulis mengajukan beberapa saran pada organisasi $\mathrm{X}$ agar dapat terus berbenah memperbaiki performa organisasinya termasuk dalam penataan sumber daya manusia. Dengan peran pengawasan oleh badan inspektorat dapat meningkatkan tingkat kedisiplinan pegawai. Secara keseluruhan, penulis mengakui bahwa penulisan ini masih banyak keterbatasan, karenanya diperlukan suatu penelitian lanjutan untuk mendapatkan gambaran yang lebih menyeluruh, baik dari segi substansi maupun metode penelitian yang digunakan.

\section{DAFTAR PUSTAKA}

Dessler, G. (2017). Manajemen Sumber Daya Manusia. In Pelatihan dan Pengembangan.

Hamzah, A. (2020). Wewenang inspektorat pengawasan daerah polda dalam pencegahan tindak pidana korupsi di kepolisian daerah sulawesi tengah. Tadulako Mater Law Journal, $\quad 4(1), \quad 1-24$. http://jurnal.untad.ac.id/jurnal/index.php/TMLJ/article/view/11344/pdf

Iskandar, D. (2019). Menutup celah korupsi melalui kolaborasi antar aktor dalam pengawasan keuangan negara. Jurnal Ilmiah Ilmu Pemerintahan. https://doi.org/10.14710/jiip.v4i1.4748

Kurniadewi, E. (2016). Psychological Capital dan Workplace Well-Being sebagai Prediktor bagi Employee Engagement. Jurnal Psikologi Integratif, 4(2), 95-112.

Mubyl, M., Dwinanda, G., \& Manajemen, J. (2019). Peran Subjective Well-Being , Kepemimpinan Transformasional Dan Komitmen Organisasional. 8(1), 74-85.

Permana, A., Aima, M. H., Ariyanto, E., \& Nurmahdi, A. (2019). The effect of leadership style, motivation and discipline of employee performance with understanding of islamic work ethics. International Journal of Scientific and Technology Research.

Rahmi, A., Achmad, G. N., \& Doddy, A. (2020). The Effect of Leadership and Empowerment Style and Motivation on Work Discipline and Employee Performance in Sungai Kunjang Subdistrict, Samarinda City. International Journal of Business and Management Invention, 9(03), 8-14.

Razak, A., Sarpan, S., \& Ramlan, R. (2018). International Review of Management and Marketing Effect of Leadership Style, Motivation and Work Discipline on Employee Performance in PT. ABC Makassar. International Review of Management and Marketing, 88(6), 67-71.

Setiawan, E., \& Mardalis. (2015). Pengaruh Gaya Kepemimpinan dan Komitmen Organisasi Terhadap Disiplin Kerja dengan Kepuasan Kerja Sebagai Variabel Intervening. Jurnal Ekonomi Manajemen Sumber Daya. Program Studi Magister Manjemen Program Pascasarjana Universitas Muhammadiah Surakarta.

Sudharta, V. A. (2017). Gaya Kepemimpinan Kepala Sekolah Dalam Perspektif Psikologi. Jurnal Manajemen Dan Supervisi Pendidikan. 
https://doi.org/10.17977/um025v1i32017p208

Suhendra, R. H. (2020, September 09). Ketua KPK Firli Bahuri Terbukti Langgar Kode Etik. https://www.cnnindonesia.com/nasional/20200924102805-12-550281/ketuakpk-firli-bahuri-terbukti-langgar-kode-etik

Sutrisno, E. (2019). Manajemen Sumber Daya Manusia (ed1). Jakaarta: Kencana.

Tama, P. I., \& Haediningtyas, D. (2017). Psikologi Industri Dalam Perspektif Sistem Industri. Malang: UB Press.

Telaumbanua, D. (2020). Restriktif Status Dewan Pengawaskpk. Jurnal Education and Development.

Wulan, D. K., \& Putri, M. (2016). Job Demands Dan Workplace Well-Being Pada Guru Sekolah Luar Biasa Negeri. JPPP - Jurnal Penelitian Dan Pengukuran Psikologi. https://doi.org/10.21009/jppp.051.05

Yudi Prawira Jaya, K., \& Dewi Adnyani, I. (2015). Pengaruh Gaya Kepemimpinan Terhadap Disiplin Kerja Pegawai Di Dinas Balai Bahasa Provinsi Bali. E-Jurnal Manajemen Universitas Udayana.

Yusuf, N. (2018). Pengaruh Kepemimpinan, Tanggung Jawab, Kedisiplinan Dan Kerjasama Terhadap Kinerja Pegawai di Universitas Gorontalo. Gorontalo Development Review, 1(1), 15. https://doi.org/10.32662/golder.v1i1.111 